\title{
From Warfare to Welfare States? Social and Military Spending in the Baltic States 1918-1940
}

VAIDAS MORKEVIČIUS, ZENONAS NORKUS, JURGITA MARKEVIČIŪTE் Institute of Sociology and Social Work, Faculty of Philosophy, Vilnius University, Lithuania

Baltic Connections Conference 2021

Virtual Conference, Zoom software

20-21 April 2021, Economic and Social History, University of Helsinki

Panel 6A: Interwar State and Economic Development

This research was funded by the European Social Fund according to the measure No. 09.3.3-LMT-K-712 „Improvement of researchers' qualification by implementing world-class R\&D projects" 


\section{Background}

- Data on interwar social and military spending (as well as any other social-political-economic statistics) in the Baltic states is mostly available only for local experts

- Project "Historical Sociology of Modern Restorations: A CrossTime Comparative Study of Post-Communist Transformation in the Baltic States" (among other things) focuses on collecting some most important interwar statistics of the Baltics and making it available for the international audience

- www.lidata.eu/en/BalticHistory

- Documented in English (and native or other international languages)

- Freely available for use (CC BY-SA 4.0) starting from 2022 
= Historical Statistics of the Baltic States = Baltijos šalių istorinè statistika

Estonia $=$ Estija

HISTAGR: Economy: agriculture, forestry and fishing = Ūkis: žemès, mišku ir vandens ūkis

$\boxplus$ Numbers of Cattle in Estonia Province, Estonia, 1897-1914 = Galviju skaičius Estijos (Estliandijos) gubernijoje, Estija, $1897-1914 \mathrm{~m}$.

$\boxplus$ Numbers of Pigs in Estonia Province, Estonia, 1897-1914 = Kiauliu skaičius Estijos (Estliandijos) gubernijoje, Estija, $1897-1914 \mathrm{~m}$.

\pm Numbers of Cattle in Livonia Province, Estonia and Latvia, 1897-1914 = Galviju skaičius Livliandijos gubernijoje, Estija ir Latvija, 1897-1914 m.

$\boxplus$ Numbers of Pigs in Livonia Province, Estonia and Latvia, 1897-1914 = Kiauliu skaičius Livliandijos gubernijoje, Estija ir Latvija, $1897-1914$ m.

$\boxplus$ Numbers of Cattle in Estonia, 1919-1939 = Galviju skaičius Estijoje, 1919-1939 m.

$\boxplus$ Numbers of Horse in Estonia 1919-1939 = Arkliu skaičius Estijoje, 1919-1939 m.

$\boxplus$ Numbers of Pigs in Estonia, 1919-1939 = Kiauliu skaičius Estijoje, 1919-1939 m.

$\boxplus$ Numbers of Sheep in Estonia, 1919-1939 = Avių skaičius Estijoje, 1919-1939 m.

- HISTEDU: Education

⿴囗十 HISTEDU: Numbers of Primary Schools in Estonia, 1919-1939 = Pradinių mokyklu skaičius Estijoje, 1919-1939 m.

廿 HISTEDU: Numbers of Secondary Schools in Estonia, 1919-1939 = Viduriniu mokyklu skaičius Estijoje, 1919-1939 m.

m HISTCOM: Industry: trading = Ūkis: prekyba

$\boxplus$ Estonian Exports, 1920-1939 = Estijos eksportas, 1920-1939 m.

๑ Estonian Imports, $1920-1939$ = Estijos importas, 1920-1939 m.

$\boxplus$ Estonian Index of Imports and Exports, 1920-1939 = Estijos importo ir eksporto indeksas, 1920-1939 m.

n HISTDEM: Population = Gyventojai

甲 Population Movement in Estonia Province, Estonia, 1897-1914 = Gyventoju judèjimas Estliandijos gubernijoje, Estija, $1897-1914$ m.

$\boxplus$ Population Movement in Livonia Province, Estonia and Latvia, 1897-1914 = Gyventoju judejimas Livliandijos gubernijoje, Estija ir Latvija, $1897-1914 \mathrm{~m}$.

$\boxplus$ Population Movement in Estonia, 1919-1939 = Gyventoju judéjimas Estijoje, 1919-1939 m.

$\boxplus$ Population of cities and towns in Estonia (within interwar borders), 1897-1939 = Estijos (tarpukario ribose) miestu ir miesteliu gyventojai 1897-1939 m.

$\boxplus$ Estonian Population by Sex and Age in 1934 Census Data = Estijos gyventojai pagal lytị ir amžiu $1934 \mathrm{~m}$. surašymo duomenimis

⿴囗十 Estonian Population by Sex and Age in 1922 Census Data = Estijos gyventojai pagal lytị ir amžiu $1922 \mathrm{~m}$. surašymo duomenimis

m HISTFIN: Finance = Finansai

$\boxplus$ Central government revenue in Estonia, 1921-1940 = Valstybès biudžeto pajamos Estijoje, 1921-1940

$\boxplus$ Central government expenditure in Estonia: state institutions, 1920-1940 = Valstybès biudžeto išlaidos Estijoje: valstybès institucijos, $1920-1940$

$\boxplus$ Central government expenditure in Estonia: purpose, 1927-1940 = Valstybès biudžeto išlaidos Estijoje: tikslai, 1927-1940

$\boxplus$ Central Government General Debt in Estonia, 1922-1939 = Estijos valstybés bendroji skola, 1922-1939 m.

$\boxplus$ Central Government External Debt in Estonia, 1922-1939 = Estijos valstybés užsienio skola, 1922-1939 m.

n HISTPRI: Prices $=$ Kainos

$\boxplus$ Annual Average Retail Prices of Food in Estonia, 1913-1939 = Maisto produktu vidutinès metinès mažmeninès kainos Estijoje $1913-1939 \mathrm{~m}$.

$\boxplus$ Annual Average Retail Prices of Non-Food Goods in Estonia, 1913-1939 = Ne maisto prekių vidutinés metinés mažmeninés kainos Estijoje 1913-1939 m.

$\boxplus$ Latvia = Latvija

$\boxplus$ Lithuania = Lietuva

Baltic States (integrated data) $=$ Baltijos šalys (jungtiniai duomenys)

$\rightarrow$ HISTDEM: Population = Gyventojai 


\section{Basic idea}

- In this presentation we look at the growth of the relative levels of social spending in the Baltic states

- Presentation based on the paper: https://doi.org/10.1080/03585522.2020.1716060

- How (if at all) transformation of the Baltic states into the "welfare states" happened during the interwar period?

- Very little research in this area (almost exclusively in local languages, country studies of specific aspects)

- Can we talk about the Baltic states as a "group of similar countries" in this respect (welfare state development), or the paths/trends were different?

- Were trends similar to other Central European countries?

- Were trends similar to the Nordic countries?

- How can we explain differences (if any) from one another and/or other ("similar") countries? 


\section{Disclaimer}

- Specific definition of welfare state

- Due to the lack of comparative data (hopefully, temporary) we focus on the relation between the social vs. defense spending patterns by the central governments

- Many gaps in historical statistics of national income

- Only spending by the central governments

- Mostly quantitative study

- Though some qualitative analysis

- Still more exploratory, than explanatory

- Though we try to provide some explanations 


\section{Welfare state: definition}

- Many approaches to define

- Britannica Online Encyclopedia: form of government in which the state protects and promotes the economic and social well-being of the citizens, based upon the principles of equal opportunity, equitable distribution of wealth, and public responsibility for citizens unable to avail themselves of the minimal provisions for a good life

- Can be measured on the output vs. input side

- Human development indicator (HDI) of the United Nations Development Programme (UNDP) measures the output of the welfare state and is derived from the economic output (GDP), health (life expectancy) and education performance data

- However, UNDP also provides a Sivard's index which is based on the size and structure of government spending that characterize the welfare state from the input side 


\section{Welfare state: Sivardian definition}

- Data driven approach

- You may develop the most elaborate definition, however, it all boils down to the measurement issue

- What data (indexes/measures) are available for historical analysis?

- Studies of less developed countries are extremely difficult (Brzoska, 1995)

- Used by the UNDP (in Human Development Reports to rank developing countries)

- Ruth Leger Sivard $(1974,1975,1976,1978,1996)$ devised a measure of the social orientation of central government expenditure (CGE) which relies on the ratio of social to military spending

- UNDP index relies on health and education expenditures

- CGE data are most readily available, even for the less developed countries 


\section{Welfare state: our definitions}

- In the context of research on transition to welfare states we modify Sivard's index in two ways

- Sivardian index 1 (SI1): following Lindert (2004) for comparative purposes we include into ratio calculation only the social transfers (CG spending on welfare and unemployment relief, subsidies to old-age pensions, subsidies to health care and subsidies for housing) as these are most directly associated with the emergence of the welfare state (increased levels of social transfers or redistribution)

- SI1 = CG social transfers (\% of total outcome at current prices) / CG defense spending (\% of total outcome at current prices)

- Sivardian index 2 (SI2): for the purpose of more nuanced analysis we also use the expanded version of SI1, which measures total social expenditures and includes into ratio calculation CG spending on education

- $\quad$ SI2 = CG otal social expenditures (\% of total outcome at current prices) / CG defense spending ( $\%$ of total outcome at current prices) 


\section{Welfare state: our definitions}

- We do not delve into research on trade-offs between military and social expenditures (ME vs. SE)

- However, we argue that former warfare state qualifies as the minimal welfare state, if SI $1>1$ and $\mathrm{SI} 2>1$

- If values of both indexes are $<1$, a state is still warfare state

- If the value of only one of two indexes is $>1$, then it is a transitional state, with the rise of the welfare state still incomplete

- Taking further guidance from the democratic transition studies, we could make further differentiation between consolidated and unconsolidated welfare states, relating consolidation threshold to SI values exceeding several times the $S I=1$ 


\section{Welfare state: our definitions}

- Differently from the total economic output, gapless and reliable CGE data are available for much larger number of countries or longer periods

- Limitation to CGE data

- It makes appear federal states more militaristic than they are in fact

- Exclusion of the local government expenditure may be justified on two grounds

- At this time no encompassing datasets on the GGE for our period are available

- There is much less variation in the structure of local government expenditure than in the CGE structure

- CGE structure more directly discloses the government's policy preferences, relevant for explanation of the overall advancement of the welfare state

- Relief and charity are historically universal tasks of local authorities, while military affairs are specialization area of the central government, so only when CG spend for social needs more than for military, they can be designated as welfare states 


\section{International comparison of SE in 1930}

- Countries included into "larger" comparison (30)

- All data available (21)

- Australia, Austria, Belgium, Denmark, Estonia, Finland, France, Germany, Ireland, Italy, Japan, Latvia, Lithuania, the Netherlands, New Zealand, Norway, Spain, Sweden, Switzerland, U.K., U.S.

- Data on educational expenditures not available (9)

- Bulgaria, Canada, Czechoslovakia, Greece, Hungary, Poland, Portugal, Romania, Yugoslavia 


\section{International comparison of SE in 1930}

- Baltic States emerged after the WW I and independence wars as real "warfare states" as their military spending made up to $2 / 3$ of total government spending in 1918-1920

- Mostly financed by Western credits

- However, in terms of state (economic) capacity (measured by central government revenue as \% of total output at current prices) the Baltic states could be considered at the average level $(\sim 14 \%)$ with the exception of Lithuania (22.9\%)

- Among three Baltic countries, only Latvia's shares of total social transfers $(2.12 \%)$ and total social spending $(4.15 \%)$ in total output were above sample mean values $(1.33 \%$ and $3.30 \%$ correspondingly)

- Latvia's comparative performance was quite impressive, as it was next only to Germany (4.96\%) and Denmark (4.4\%)

- Shares of Estonia (1.34\% and $3.38 \%$ ) nearly corresponded to sample mean

- Lithuania's share of social transfers $(0.39 \%)$ was markedly below sample mean, while the share of total social spending (3.24\%) was close to mean 


\section{SE \& ME in the Baltic states in 1930}

- What about the SE vs. ME ratios in the Baltic states (during the whole interwar period)?

- SI1 (SE (no education exp.) vs. ME)

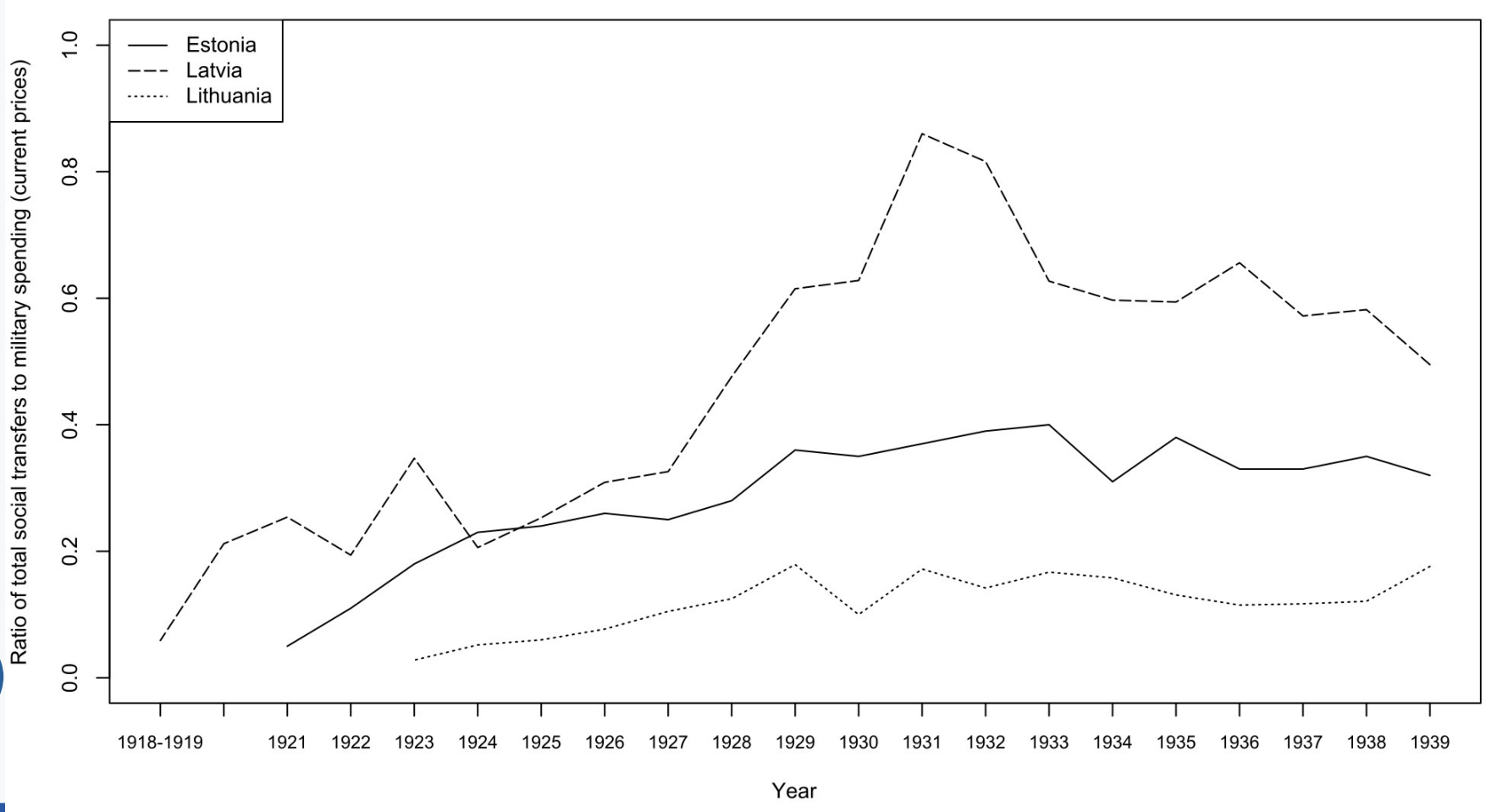




\section{SE \& ME in the Baltic states in 1930}

- What about the SE vs. ME ratios in the Baltic states (during the whole interwar period)?

- SI2 (SE (with education exp.) vs. ME)

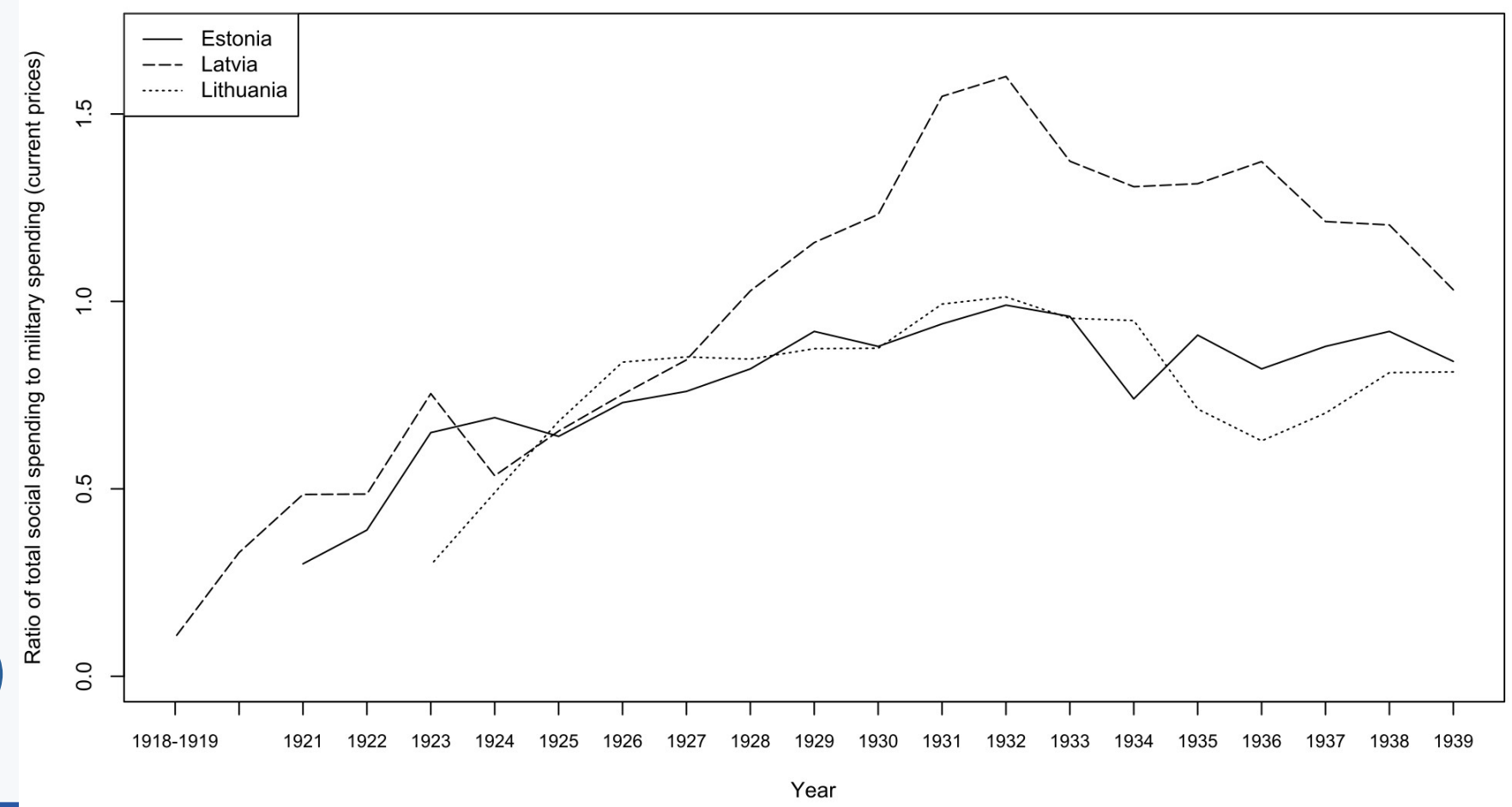




\section{Explaining SE \& ME in interwar Baltics}

- Why did Latvia stand out?

- In the background of common legacy of Russian Empire that had low levels of SE

- In Lithuania

- Extension of social insurance was slow and did not include agricultural population (no unemployment benefits)

- Pension system was introduced very late and targeted mostly towards civil servants

- Territorial sickness funds were introduced in only 1929 and were very limited

- In Estonia

- Pension law was passed already in 1924 (however, covered only former state employees)

- Health insurance was limited to urban population

- Extent of social insurance was also limited (no unemployment benefits)

- In Latvia

- Health insurance was more extensive and from 1928 covered agricultural sector

- More comprehensive social insurance was introduced in 1930 (still, no unemployment benefits)

However, the pension system was still not inclusive 


\section{Explaining SE \& ME in interwar Baltics}

- Can knowledge accumulated by international research on the rise of welfare state help to explain the cross-national standing of Baltic countries in the welfare state transition by 1930 and to account for causes of the uneven progress towards the welfare state among Baltic countries themselves during entire interwar period?

- Economic development (e.g. Wilensky, 1975; Rimlinger, 1982)

- Democratization (e.g. Janoski \& Hicks, 1994; Lindert, 1994, 2004)

- State (economic) capacity (e.g. Dincecco, 2017; Dincecco \& Onorato, 2018; Peacock \& Wiseman, 1961) 


\section{Explaining SE \& ME in interwar Baltics}

- Can knowledge accumulated by international research on the rise of welfare state help to explain the cross-national standing of Baltic countries in the welfare state transition by 1930 and to account for causes of the uneven progress towards the welfare state among Baltic countries themselves during entire interwar period?

- Economic development: total output per capita at PPP

- Democratization: V-Dem (Coppedge et al., 2019), which is the most recent addition to the library of political regimes measurement

- State (economic) capacity: revenue of CG (in \% of total output) 


\section{Explaining SE \& ME in interwar Baltics}

- OLS regression results with SI1 as dependent variable

\begin{tabular}{|c|c|c|c|c|c|c|c|}
\hline Dependent & \multicolumn{7}{|c|}{ SI 1} \\
\hline Independent & Model 1 & Model 2 & Model 3 & Model 4 & Model 5 & Model 6 & Model 7 \\
\hline Constant & $\begin{array}{l}1.383 * * * \\
(0.001)\end{array}$ & $\begin{array}{l}1.383 * * * \\
(0.000)\end{array}$ & $\begin{array}{l}1.383 * * * \\
(0.001)\end{array}$ & $\begin{array}{l}1.383 * * * \\
(0.000)\end{array}$ & $\begin{array}{l}1.383 * * * \\
(0.001)\end{array}$ & $\begin{array}{l}1.383 * * * \\
(0.000)\end{array}$ & $\begin{array}{l}1.383 * * * \\
(0.000)\end{array}$ \\
\hline $\begin{array}{l}\text { GDP per capita } \\
\text { (1990 Int. GKS) }\end{array}$ & $\begin{array}{l}0.759^{*} \\
(0.051)\end{array}$ & & & $\begin{array}{r}-0.030 \\
(0.947)\end{array}$ & $\begin{array}{r}0.571 \\
(0.198)\end{array}$ & & $\begin{array}{r}-0.235 \\
(0.631)\end{array}$ \\
\hline $\begin{array}{l}\text { V-Dem: Liberal } \\
\text { democracy index }\end{array}$ & & $\begin{array}{l}1.198 * * * \\
(0.001)\end{array}$ & & $\begin{array}{r}1.217 * * * \\
(0.010)\end{array}$ & & $\begin{array}{r}1.099 * * * \\
(0.004)\end{array}$ & $\begin{array}{r}1.226 * * * \\
(0.010)\end{array}$ \\
\hline $\begin{array}{l}\text { CG Revenue (\% } \\
\text { total output) }\end{array}$ & & & $\begin{array}{l}-0.660 * \\
(0.092)\end{array}$ & & $\begin{array}{r}-0.370 \\
(0.400)\end{array}$ & $\begin{array}{r}-0.314 \\
(0.373)\end{array}$ & $\begin{array}{r}-0.392 \\
(0.320)\end{array}$ \\
\hline $\mathbf{R}^{2}$ & 0.130 & 0.323 & 0.098 & 0.323 & 0.153 & 0.343 & 0.349 \\
\hline Adjusted $\mathbf{R}^{2}$ & 0.099 & 0.299 & 0.066 & 0.273 & 0.090 & 0.294 & 0.274 \\
\hline $\mathbf{N}$ & 30 & 30 & 30 & 30 & 30 & 30 & 30 \\
\hline
\end{tabular}




\section{Explaining SE \& ME in interwar Baltics}

- OLS regression results with SI2 as dependent variable

\begin{tabular}{|c|c|c|c|c|c|c|c|}
\hline \multirow{2}{*}{$\begin{array}{c}\text { Dependent variable } \\
\text { Independent variables }\end{array}$} & \multicolumn{7}{|c|}{ SI 2} \\
\hline & Model 1 & Model 2 & Model 3 & Model 4 & Model 5 & Model 6 & Model 7 \\
\hline Constant & $\begin{array}{l}3.066^{* * *} \\
(0.001)\end{array}$ & $\begin{array}{l}3.066 * * * \\
(0.000)\end{array}$ & $\begin{array}{l}3.066 * * * \\
(0.000)\end{array}$ & $\begin{array}{l}3.066 * * * \\
(0.000)\end{array}$ & $\begin{array}{l}3.066 * * * \\
(0.001)\end{array}$ & $\begin{array}{l}3.066 * * * \\
(0.000)\end{array}$ & $\begin{array}{l}3.066 * * * \\
(0.000)\end{array}$ \\
\hline GDP per capita (1990 Int. GKS) & $\begin{array}{r}0.583 \\
(0.448)\end{array}$ & & & $\begin{array}{c}-0.347 \\
(0.648)\end{array}$ & $\begin{array}{r}0.289 \\
(0.753)\end{array}$ & & $\begin{array}{r}-0.635 \\
(0.475)\end{array}$ \\
\hline V-Dem: Liberal democracy index & & $\begin{array}{r}1.787 * * \\
(0.012)\end{array}$ & & $\begin{array}{r}1.953 * * \\
(0.018)\end{array}$ & & $\begin{array}{r}1.721 * * \\
(0.021)\end{array}$ & $\begin{array}{r}1.950 * * \\
(0.020)\end{array}$ \\
\hline CG Revenue ( $\%$ total output) & & & $\begin{array}{c}-0.701 \\
(0.359)\end{array}$ & & $\begin{array}{r}-0.546 \\
(0.555)\end{array}$ & $\begin{array}{r}-0.255 \\
(0.731)\end{array}$ & $\begin{array}{r}-0.536 \\
(0.507)\end{array}$ \\
\hline $\mathbf{R}^{2}$ & 0.031 & 0.289 & 0.044 & 0.297 & 0.050 & 0.294 & 0.316 \\
\hline Adjusted $\mathbf{R}^{2}$ & -0.020 & 0.251 & -0.006 & 0.219 & -0.056 & 0.216 & 0.195 \\
\hline $\mathbf{N}$ & 21 & 21 & 21 & 21 & 21 & 21 & 21 \\
\hline
\end{tabular}




\section{Explaining SE \& ME in interwar Baltics}

- The significance of these findings should not be overrated, because 'social policies were introduced with different motivation in different places and the various factors have carried different weight in different periods' (Kuhnle \& Sander, 2010, p. 67)

- How can they explain why Latvia having comparatively high levels of SE was still at best "transitional welfare state"?

- Let's look at the relation between the SE and ME vs. democratization 


\section{Expl}

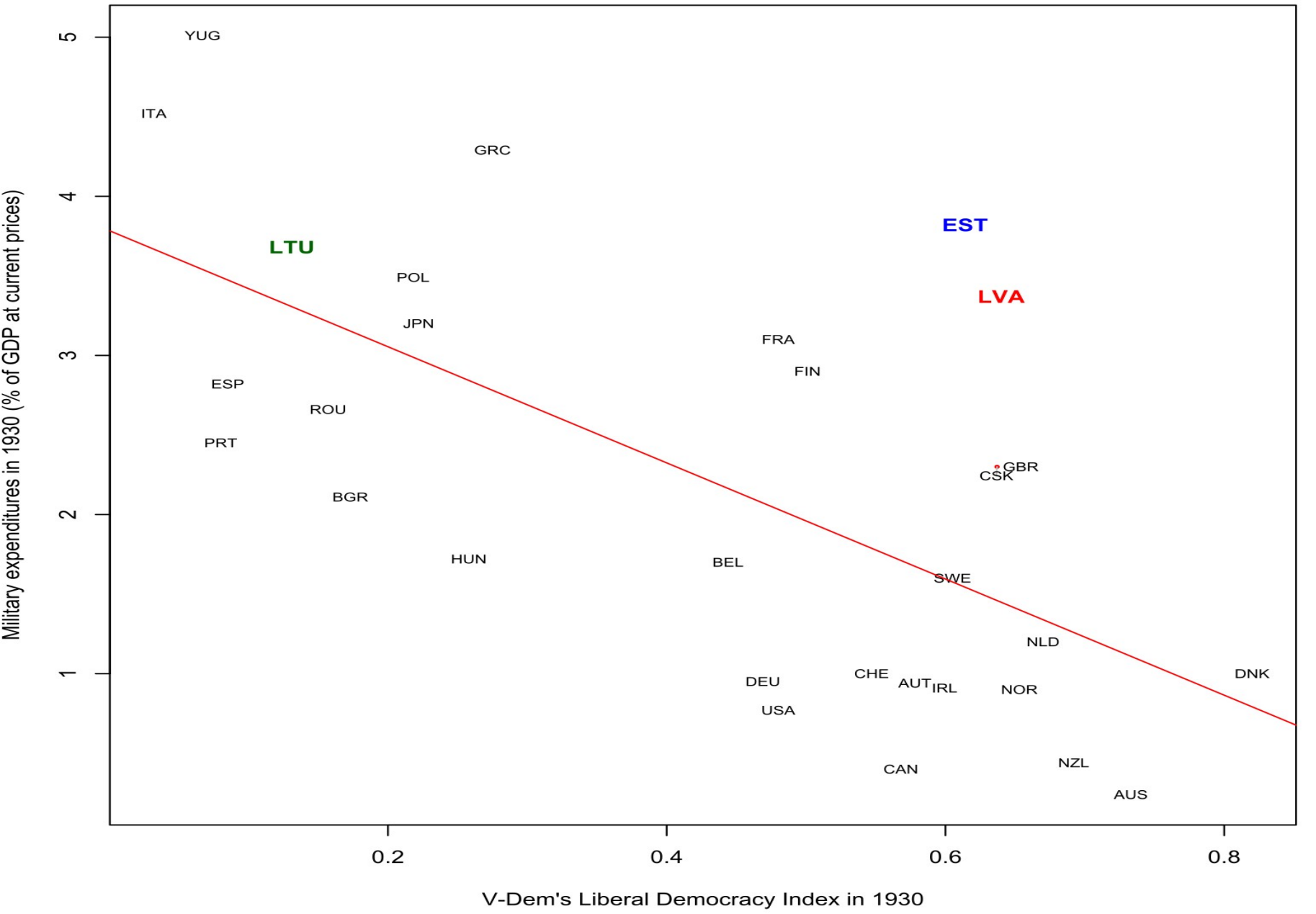




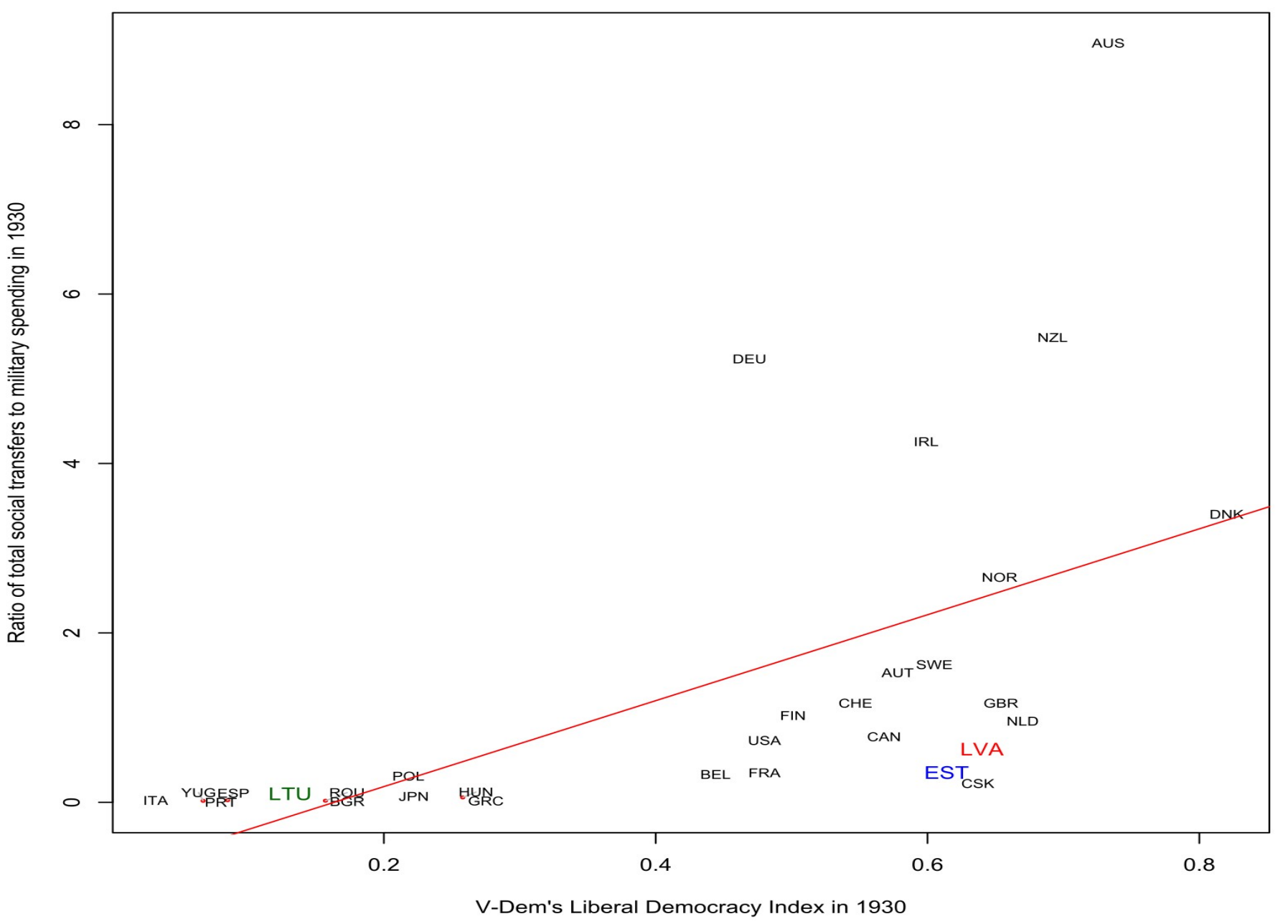




\section{Explaining SE \& ME in interwar Baltics}

- How can they explain why Latvia having comparatively high levels of SE was still at best "transitional welfare state"?

- The absence of democracy nearly completely accounted for the (weak) social orientation of the CGE in Lithuania (measured by both versions $\mathrm{SI}$ ) in 1930

- However, Latvia and Estonia did emerge as outliers, with the social orientation of CGE much less than predicted

- In 1930, Estonia and Latvia outspended militarily countries on the similar level of liberal democracy, while Lithuania's military spending was as predicted from its very low score on liberal democracy

- Why Estonia and Latvia's military expenditure was higher than predicted from their democracy scores, precluding Estonia from taking off the transition to welfare state (with its SI1and SI2 less than 1), and preventing Latvia from completing this transition (with SI1 < 1 and SI2 >1)?

- Why Latvia did move further on this way, although democratisation and military spending levels of Estonia and Latvia were very close? 


\section{Explaining SE \& ME in interwar Baltics}

- How can they explain why Latvia having comparatively high levels of SE was still at best "transitional welfare state"?

- Most credible answer to the first question

- With no powerful geopolitical allies, Baltic countries could rely only on themselves, high levels of military spending serving to provide some of self-assurance

- The only difference was that for Lithuania this was the self-assurance against Poland (conflict over Vilnius region), while for Estonia and Latvia - against the Soviet Union (see e.g. Butkus, 2019; Hiden, 1987; Illmjärv, 2004).

- Most credible answer to the second question

- Since the strength of social democratic parties in the Nordic countries was the main cause of the early consolidation of the welfare state in these countries, it may be applicable in the Baltic countries

- Lithuanian government was early (late 1926) taken by the right-authoritarian coup

- Failed attempt of the Communist coup in Tallinn on 1 December 1924 had strong retarding effects (legal socialists parties were looked upon with suspicion) on the advancement of the welfare state in Estonia

- Only Latvia had for more prolonged period (1925-1934) politically influential social democratic parties 


\section{Further research direction}

- Other causal factors in the quantitative (OLS regression) analysis

- Strength of leftist parties, trade unions, socio-cultural homogeneity, etc.

- Use of GGE data

- Add expenditure data of local administrations

- Improve indicators of national income estimates

- The use of Sivardian index provides only working substitute for missing total output data

- New estimates of GDP in the contemporary uniform SNA framework for all three Baltic countries may exact the revision of some claims of this study, which should be considered only as the first hypotheses or estimates 


\section{Thank you for the attention!}

vaidas.morkevicius@gmail.com 